\title{
Tehlikeli Oyunlar'a Biçimci Yaklaşım
}

\section{BİRSEL SAĞIROĞLU*}

$\ddot{O} z$

Oğuz Atay'ın (1934-1977) önemli eserlerinden biri olan Tehlikeli Oyunlar 1973 yılında yazılır. Yazıldığı dönemle ilgili çeşitli ipuçları barındıran eser, oyun içinde oyun tekniği, iç içe geçmiş zaman anlayışıyla ve de anlatı katmanlarındaki çeşitliliğiyle göze çarpar. Eserde okuyucuya farklı oyunlar oynayan anlatıcı, büyük bir karmaşa yaratır. Roman dört ana bölümden ve on sekiz alt bölümden oluşur. $\mathrm{Bu}$ parçalı yapı "örnek okur"un işbirliğiyle çözümlenebilecek tekinsiz bir atmosferi destekler. Bu çalışmada, Umberto Eco'nun metnin iç dinamiklerini esas alan sanat anlayışının izleri sürülecek ve Tehlikeli Oyunlar'da yer alan bazı bölümler -eklektik bir anlayışla- çalı̧̧manın amacına uygun olarak çözümlenecektir. Roman, "zaman", "okur" düzleminde yarattı̆̆ı şizoid teknik bakımından ele alınacak ve romanda "yorumlayıcı işbirliği" ile "inançsızlığın askıya alınması" kavramlarının izleri sürülecektir.

Anahtar sözcükler: Umberto Eco, söylem zamanı, örnek okur, yorumlayıc1 işbirliği, inançsızlığın askıya alınması.

\section{A FORMALIST APPROACH TO TEHLIKKELİ OYUNLAR}

\section{Abstract}

Tehlikeli Oyunlar which is one of the most important novels of Oguz Atay was written in 1973. The novel that has various clues about the period it was written comes into prominence with the technique of game within the game, intertwined time comprehension and the diversity in narration layers. The narrator of the text prepares different language games for readers and by doing this $\mathrm{s} / \mathrm{he}$ enhances

\footnotetext{
* Eskişehir Osmangazi Üniversitesi Sosyal Bilimler Enstitüsü doktora öğrencisi, birselsagiroglu@gmail.com
} 
vagueness and complexity of the text. The novel consists of four main parts and eighteen subparts. This partial structure supports an uncanny atmosphere that can be analyzed with cooperation of "representative reader". In this study, Umberto Eco's sense of art that is based on the internal dynamics of text is going to be searched and some parts in Tehlikeli Oyunlar are going to be analyzed with an eclectically understanding in line with the aim of the study. The novel is going to be handled in terms of the schizoid technique created in time and reader plane and the concepts of "interpretative cooperation" and "the suspension of disbelief" are going to be scrutinized.

Keywords: Umberto Eco, discourse time, representative reader, interpretative cooperation, the suspension of disbelief.

\section{Yorumlayıcı İşbirliği Işığında Tehlikeli Oyunlar: İntihar mı? Oyun mu?}

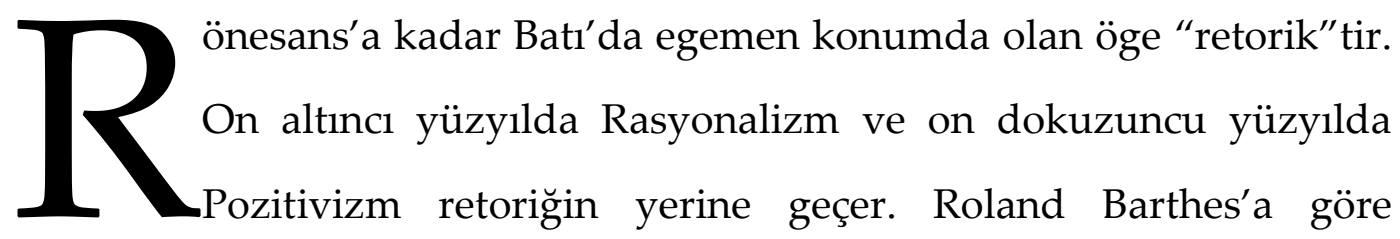

“Edebiyat Mallarme gibi birkaç öncü yazar dışında kendisini dil olarak hissetmeyi bıraktı."(2013: 20) Yazının devamında Barthes, günümüzde edebiyat ile dilbilimin yeni bir bakış açısının egemen olduğu ortak bir düşünce alanının olduğunu savunur. Yazma eyleminin dilbilim kategorisi yardımıyla ifade edilebilecek bir alan olarak tanımlar (2013: 21-22). Bu çalışmada da yöntemsel bir bakış açısıyla eserdeki nesnellik irdelenir. Metin, gerçekliği temsil ediliş biçimi bakımından değerlendirilir. Kendi bünyesinde birden fazla çoğul anlam barındıran eserin hangi söylem olanağına sahip olduğu belirlenmeye çalışılırken tarihten, yazarın kişiliği veya zevklerinden bağımsız bir ifade gücü elde edilir. Barthes'ın da vurguladığı gibi dünya yazardan yapıtının sorumluluğunu üstlenmesini ister. Fakat yazar yalnızca biçime bağlılığıyla tanınmalıdır. Yan anlamlar üreten, başkasının sözü konumundaki metni yorumlamak, bir "biçim" sorunu olmalıdır (2012: 15-17). Metnin iç dinamiklerini ve bunların sınıflandırılmasına dayanan biçime dayalı uygulayım 
olanakları, sözgelimi, metnin çelişkisini, ritmini, söylemini teknik dille ifade etmeye olanak sağlar. Buna göre Tehlikeli Oyunlar biçime dair hangi kodlarla ifade edilebilir ya da bu kodların romanda konumlanışı nasıldır?

Tehlikeli Oyunlar, Hikmet Benol'un iç dünyasını, çelişkilerini yarattığı kişilerle somutlaştıran bir eser olarak değerlendirilebilir. Otuzlu yaşlardaki Hikmet Benol, aldığı

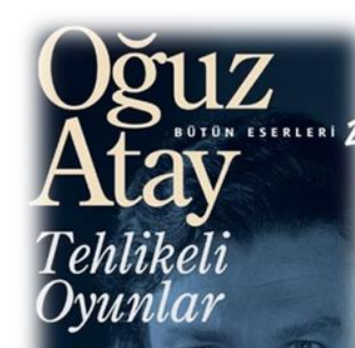
yeni kararlarla birlikte hayatını bütünüyle değiştirmek ister ve modern dünyayı terk ederek gecekonduya taşınır. Onun gecekondudaki komşuları, Albay Hüsamettin Tambay ve Nurhayat Hanım'dır. Hikmet Benol, Albayla oyunlar yazarken iç konuşmaları ve hayalleri oyunlara dâhil olur, onun iç hesaplaşması yazdığı bu oyunlarda belirginleşir. Özellikle geçmişiyle yüzleşen Hikmet Benol, yazdığ oyunlarda da başarılı olamaz ve romanın sonunda intihar eder.

12 Mart askerî darbesinden sonra yazılan bu eser, Türkiye'nin siyasi tarihi dışında, Türkiye'deki aydını, Batıcılık fikrini ve sanatı da tartışır. Yıldız Ecevit'in vurguladığı üzere romanın ana tematiği Atay'ın ilk romanında olduğu gibi ontolojiktir, konunun geçtiği yer ise bireyin ruhunun derinlikleridir (2009: 101). Yunus Şahin romanı şöyle değerlendirir:

“Eserin önemli özelliklerinden biri, hayatla oyunun yani gerçekle kurmacanın iç içe girmesidir. Romanda bilinçli olarak oyunla gerçek hayat karıştırılmış, neyin gerçek neyin kurmaca olduğu belirsizleştirilmiştir. Albay Hüsamettin ile eşi Nurhayat Hanım'ın gerçekten var olup olmadıkları belli değildir. Kendi içerisinde birçok alt karaktere bölünen Hikmet bile belli bir noktadan sonra kendi varlığından şüphe duymaktadır. Böylece Atay'ın üstkurmacayla yapmak istediği, her şeyin aslında bir kurgu olduğu gerçeğini vurgulamaktır. Başka bir deyişle Atay’a göre hayat bir oyundan ibarettir." (2014: 17)

Hikmet Benol XIV. bölümde (Büyük Oyun), gerçekle oyunu karıştırdığını itiraf eder: "Her sabah uyanınca biraz isteksiz de olsak, hepimiz sahnenin bir 
yerinde, bizi çevreleyen büyük ve uzak dünyanın sevimli bir benzerini kurmak için toplanırız. Sonunda, kendi oyunumu, bütün bu oyunların dışında ve gerçek olarak yaşamaya karar verdim." (2011: 348) O, bölümün devamında okuru şaşırtmaya devam eder, romandaki "doğruluk" dil ustalığıyla farklı boyutlara taşınır: "Sevgi ile geçen gün karşılaşan ben olsaydım, gecekondu ve Bilge ve hatta Sevgi'den ayrılmış olmam gerçekliğini kaybederdi. Yoksa Sevgi'den ayrılmadım mı? Belki de sıcak bir günün öğleden sonrasında, uzandığım kanepede uyuyakaldım." (2014: 353) Bu durumda Oğuz Atay'ın romanda bir düzen yaratmak için özel bir çaba harcadığını fakat okurun bu çabayı fark etmemesi için ayrı bir ifade gücünden yararlandı̆̆ı düşünülebilir mi? Ya da anlatıcı, bu sözleriyle okuru romanla ilgili uyarmakta mıdır, uyarıyorsa hangi konularda uyarmaktadır? Umberto Eco, Anlatı Ormanlarında Altı Gezinti adlı kuramsal çalışmasında "okur"un bu sorularını cevaplar. O, kuramında okurun metne bağlılı̆̆ını esas alır. Okur metnin dışına çıkamaz, âdeta metne hapsolur ve de tek koşulla özgürdür: metne bağlılık. Eco'nun üzerinde durduğu kavramlardan biri de "yorumlayıcı işbirliği"dir. Eco'ya göre okur, metinden metnin açıkça söylemediği şeyleri çıkarsamalı ancak okur metnin söylediklerinin tersini de söylememelidir (2015: 122). Tehlikeli Oyunlar, sözgelimi, Şahin'e göre Hikmet Benol'un intiharıyla sonlanır (2014: 15). Şenocak ise Hikmet Benol'un romanın birçok yerinde uykuya daldığını romanın bazı bölümlerinin uyku ile başlayıp uyku ile bittiğini ve bu nedenle tüm romanın "uyku" parantezine alınmış olabileceğini ifade eder (2011: 43-44). Bu durumda iki yorumdan hangisi doğrudur? Eco'ya göre birinci düzey okur veya ampirik okur kendi beklentilerini yazarın beklentilerinin önüne koyar. Metin böyle okurlar için tutkularının nesnesidir. Ayrıca ampirik okurun metni nasıl okuması gerektiğini belirleyecek bir yasa da yoktur. Hâlbuki örnek okur metinle işbirliği içindedir. Metnin yaratmaya çalıştığı okur tipidir ve metni okuması tasarlanan biçimde okur (2015: 20-21).

Romanın başında Hikmet yataktadır. Uyku ile uyanıklık arasında gidip gelen Hikmet, "Yüzükoyun yatar; başını yastığa, daha doğrusu, kılıf geçirilerek yastık hâline getirilmiş mindere bastırır." Yan odada ise Asuman ve Naciye Hanım’ın 


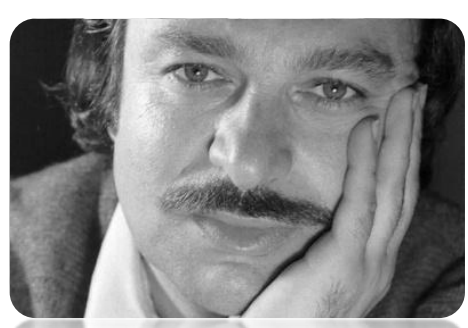

sesleri işitilir. Onların konuşmalarına Hikmet'in iç konuşmaları eşlik eder. Çok geçmeden Hikmet yatağından doğrulur ve yanı başındaki kişi Hüsamettin Bey'dir (2011: 13-20). Atay, okuyucuyla oyun oynayarak hiçbir düzlemin gerçekliğinden emin olmamamıza neden olur (Şenocak: 62). Çünkü Hüsamettin Bey'in görünmesinden sonra anlatıcı (Hikmet) okurun kafasını karıştırmaya devam eder: "Nerede olduğumu bulamıyorum Hüsamettin Bey. Aklım bir yere takıldı. Bana dayanılmaz baskılar yapıyordu. Kim? Hangi şehirde? Kollarıma, bacaklarıma... sözlerimi gayrı ciddiye... ellerimi bu korkunç boşluğa... sus... uyanınca düzelecek." (2011: 21). Bölümün (Gecekondu) devamında anlatıcı geriye sapmalarla (analeks) karısından, evliliğinden, silah arkadaşlarıyla buluşmasından bahseder. Atay, kurduğu dünyayla ilgili her şeyi söylemez. Belli noktalara değinir, kalanı için “örnek okur”dan destek bekler. Bu nedenle geçmiş zaman ile şimdiki zaman arasındaki sınır bazen kaybolur. Şenocak'ın vurguladığı gibi, örneğin, ikinci bölümde (Dul Kadın) Nurhayat Hanım’ın gelmesiyle birlikte tekrar şimdiki zamana, gecekonduya döneriz. Hidayet'in mektubunun okunmasıyla beraber kışlaya, sonra yazdığı oyunun okunması sırasında fantastik bir tiyatro âlemine geçeriz. $\mathrm{Bu}$ oyun, içerdiği Hamlet göndermeleri ile okur için aynı zamanda metinler arası bir yolculuk niteliği de taşır. Nurhayat Hanım'ın oğlu Hidayet'e göndermek üzere Hikmet'e yazdırdı̆̆ ise düzlemler iyice karışır (2011: 62).

Eco'ya göre “Her metin, okurdan onun işine katılmasını isteyen tembel bir araçtır. Bir metin, alıcının anlaması gereken her şeyi söylese mahvolurduk" (2015: 14). Romanın bu çoklu düzleminden kaynaklanan kaosun Eco'nun bu düşüncesini desteklediği düşünülebilir. Roman, geriye sapmalar (analeks) etkileyici hâle getirilir. Böylece anlatının bütününde okur geçmiş ve şimdiki zaman arasındaki parçalı anlatımda yolunu kaybeder, aynı zamanda bir seçim yapmaya da zorlanır. Bu seçimde analeks Eco'nun da vurguladığı gibi anlatıcının unutkanlığını giderme işleviyle dikkat çeker (2015: 47). Geri dönüşler aracılığıyla anlatı, zamanın akışından 
kısmen bağımsız bir yapı olarak örgütlenir, zamansal süreklilikte kesintiler ortaya çıkar (Genette 2011: 41). Romanda Hikmet, sırasıyla Albay Hüsamettin Bey, ülke, meyhane, Bilge, Sevgi, Selim Bey, mum 1şı̆̆ı, mücevherler bölümlerini geriye sapmalarla okura tanıtır. İlk iki bölümde oyunun kahramanlarına ve mekânına yer verilir. Son iki bölümde ise kavramlar (korku, düşüş, yalnızlığın oyuncakları), mimetik imgeler (son yemek, Antonious ve Kleopatra, Austerlitz Savaşı) göze çarpar. Fakat XIII. bölümde örnek okura önemli bir bilgi aktaran Hikmet “bütün bunlar benim hayalimin ürünleri" diyerek anlattıklarının kurmaca dünyaya ait olduğu konusunda okuru ikna etmeye çalışır (2011: 314). Bölümün devamında ise çelişik bir ifade dikkat çeker: “Sevgili Bilge, işte bu yüzden hayal ve gerçek, benim onlara verdiğim anlamları kaybetmek üzere. Sen yaşadığım bir gerçek misin? Yoksa bir zamanlar yaşamış olduğum bir rüya mısın? Yoksa, ikisi de değil misin?" (2011: 325) Ancak Hikmet, Sevgi'ye de şunları söyler:

“Albayları ve dul kadınları içimde taşıdığım için bu yansımalar biraz gözünü kamaştırıyordu. Belki bu satırların yazarından ve onun kafasını işgal eden senden başka gerçek bir varlık yoktur ortada. Albay'ın ve Nurhayat Hanımın nesnel birer olgu olması kuşkulu olduğu gibi, bunların dışında -ikinci dereceden olgular diyebileceğimiz- Albay’ın karısı ve askerliğini yaptığı söylenen Hidayet de gerçeküstü bir oyunun kahramanlarından ibaret olabilir." (2011: 325-326)

Ayrıca aynı bölümde mekânla ilgili çelişik bir ifade göze çarpar. Anlatıcı, otobiyografisinde “H. Tambay'ın alt katında oturduğumu, bin dokuz yüz altmış beşten sonra kafamın düzgün gitmediğini, bin dokuz yüz altmış sekizden sonra da iyice çileden çıtı̆̆ını, on yedi ocakta karımdan ayrılarak sayın hastanenize düştüğümü belirterek, benden korkmalarını yazdım." (2011: 343) Gecekonduda geçen olaylar aslında hastane odasında mı gerçekleşmiştir? Fakat romanın on birinci bölümünde Albay, Hikmet'i “Buraya gecekondu deyip durma. Gecekondu muhitine yakın, iki katlı ahşap bir evde oturuyoruz." (2011: 277) sözleriyle uyarır. Ecevit'e göre romanın başındaki uyku ile uyanıklık arasındaki kâbus sahnesi, gerçek dünyadan 
fantastik dünyaya geçişi sembolize eder (2007: 356). Bu çelişik ifadeler yine anlatıcının oyunlarından biri olup "düşüş" bölümünde açıklı̆̆a kavuşur: "Bir zamanlar bir Hikmet vardı. Üç katlı ahşap bir evde yaşardı. Bu gecegeldide Hikmet'ten başka galiba iki şey daha vardı, roman kahramanı gibi iki şey. Bunların yaşayıp yaşamadıkları tam belli değildi." (2011: 456) Böylece Nurhayat Hanım'ın, Hüsamettin Tambay'ın ve gecekondunun oyunun bir parçası olduğu fark edilir. Aynı zamanda oyunun esas mekânı da Hikmet'in "gecekondu" olarak tanımladığı ahşap ve üç katlı bir evdir. Bu gerçeklik, Hikmet'in kurmaca dünyasıyla açıklığa kavuşur. Bu nedenle hastane onun oyununun bir parçası olarak değerlendirilebilir. Çünkü anlatıcı otobiyografisinde inandırıcıllğı artıracak pek çok ayrıntı hakkında bilgi verirken gerçekle kurmacayı karıştırarak okuru yanıltmaya çalışır. Sözgelimi, "I. B'ye kayıt olduğumu, 764 no.lu öğrenci olduğumu, dört kere bahçede düştügümü" gibi gerçek dünyaya ait birçok detayı paylaşan anlatıının biyografinin sonunda mekân konusunda (hastane) tekrar kurmacaya başvurarak okurun zihnini bulandırmaya çalıştığı düşünülebilir. Ancak okurun bu bilgilerden anlaması gereken şey, romanda bir düzen yoksunluğundan çok anlatıcının izlediği düzenin ilk bakışta kendini fark ettirmemesidir. Eco, “örnek yazar"1 metnin anonim sesi olarak tanımlar. Bu ses, metnin yazarı ya da anlatıcı değildir ve eserin içinde okurla konuşur, okuru yanında ister ve metnin defalarca okunmasını talep eder (2015: 28-29). Tehlikeli Oyunlar'da baskın konumdaki anlatıcı Hikmet Benol'dur. Birinci tekil kişi ağzından yazılan romanda örnek yazarın değişik varsayımsal sesleri karıştırarak anlatımda yeni stratejiler elde ettiği fark edilir. Bu seslerin örnek yazarı temsil ettiği düşünüldügünde örnek okuru zor bir görev beklemektedir: Kaos ortamını bir düzene sokmak ve anlatıyı anlamlandırmak. Tehlikeli Oyunlar'ın örnek okuru bu nedenle metni bir kere okumakla yetinmeyecek, metnin kurallarını sezen okur, oyunda kalacaktır.

Çalışmanın başında Şahin'in ve Şenocak'ın romanın sonuyla ilgili farklı tahminlerine yer vermiştik. Şahin, Hikmet Benol'un intihar ettiğini Şenocak ise tüm 
romanın "uyku"dan ibaret olduğunu ifade etmişti. Romanın XVII. ve XVIII. bölümlerinde Hikmet Benol'un intihar ettiğine dair net ifadeler göze çarpar. Sözgelimi XVII. bölümde Hikmet Benol intiharın hazırlığg içindedir ve bölüm onun şu sözleriyle sona erer: "Parmaklığa dayandım albayım. Belki de bu parmaklıklar zayıftır, ne dersiniz? İnsanın ağırlığına dayanmaz sonra. Artık çok geç, geriye bakamam. Neden geriye dönemiyorum? Aşağı da bakamıyorum. Gözlerini kapa. Buraya takıldım kaldım (2011: 462). Son bölümde ise Hikmet Benol intihar etmiştir:

\begin{abstract}
“Nurhayat Hanım, sandığından, sandığın dibindeki çarşaflardan beyaz bir tanesini çıkararak Hikmet'in üstüne örtmüştü. Daha önce gelerek ilk sırayı alanlar, 'Hiçbir tarafına bir şey olmamış kardeş.' diye arka sıralardaki meraklılara anlatıyorlardı. 'Bir tarafında bir sıyrık bile yoktu: Sanki rahatça uzanmış yatıyordu." (2011: 465)
\end{abstract}

Son bölümde örnek yazar okuru bölümün başlığıyla uyarır. Çünkü roman "Albay Girer" bölümüyle sonlandırılır. Hâlbuki daha önceki bölümlerde Albay Hüsamettin Tambay ve Nurhayat Hanım'ın oyunun bir parçası olduğu Hikmet Benol tarafından birkaç kez ifade edilmişti. Kaldı ki kitabın son sayfasında Albay'ın şu sözleri Hikmet'in ölmediği ya da romandaki oyunun devam ettiği yönündeki iddiaları güçlendirir:

$$
\begin{aligned}
& \text { "Anlamıyorum" diye mırıldandı Hüsamettin Bey. "Neler } \\
& \text { olduğunu hakikaten hatırlamıyorum Hikmet. Sen bana müsait } \\
& \text { bir zamanında anlatırsın olmaz mı?" Kâğıtları topladı: "İfade } \\
& \text { edemediğim bir eksiklik hissi var içimde, Hikmet oğlum. Sanki } \\
& \text { her şey başka türlü oynanabilirdi." Odadan çıktı, kapıyı } \\
& \text { yavaşça kapadı." (2011: 474) }
\end{aligned}
$$

Örnek okura düşen görev, bu durumda, ipuçlarından yola çıkarak örnek yazarın kurduğu dünyayla ilgili söylemediği tarafları açıklığa kavuşturmaktır. Buna göre, romanın tamamı Hikmet Benol'un oyununun bir parçasıdır. Fakat oyunun art alanını onun "gerçek hayatı" oluşturur. Örneğin, Sevgi ile evliliği, Bilge'ye olan aşkı ve arkadaşları gerçek dünyadan alınan parçalardır. Albay onun kurmaca dünyasına 
aittir, bu nedenle albayın anlatıcılığı üstlendiği son bölüm de (Albay Girer) kurmacadır. Kurmaca devam ettiğine göre kurmacanın yazarı yani Hikmet Benol intihar etmemiştir sonucuna varılabilir. Eco, herhangi bir anlatıda bu durumu, anlatıcının okura gereğinden fazla şey söylememesiyle açıklar. Metinde gereğinden fazla ayrıntıya yer verildiği takdirde metnin gelişimi zarar görür. Bununla birlikte bir metinde bir ayrıntıya yer verilecekse bu "detay" anlatı için vazgeçilmez olmalıdır (2015: 115). Atay da uzun soluklu bu romanda ilkin karmaşa yaratır sonrasında da örnek okurun farkına varabileceği ayrıntılarla karmaşadan bir "düzen” oluşturur. Bu düzende iki ayrı dünya (kurmaca-gerçek) dışında anlatıcının rüyaları da vardır. Bu durumda örnek okur, romanla ilgili şu sonuçlara varabilir:

\begin{tabular}{|c|c|}
\hline Gerçek & Kurmaca \\
\hline üç katlı ahşap ev & Gecekondu \\
\hline Hikmet Benol, Sevgi, Bilge & Albay, Nurhayat Hanım \\
\hline $\begin{array}{c}\text { uyku ve uyanıklık arasındaki } \\
\text { hâl }\end{array}$ & Hikmet'in intiharı \\
\hline
\end{tabular}

\section{Tehlikeli Oyunlar'da Oyalanmak}

Bu bölümde Atay'ın romanı "oyalama tekniği" ve "söylem zamanı" bakımından ele alınacaktır. Eco, bu kavramlarla bir metnin niçin oyalandığını veya zamanı yavaşlatıp uzattığını sorgular. Metindeki zamanın durağan veya geciktirici olabileceğini ifade eden Eco, oyalanmanın önemli ya da ilgi çekici bir şeyin ortaya çıkması için kullanılabileceğini ve bunun "vakit kaybetmek" anlamına gelmeyeceğini de ekler. Çünkü oyalanmalar okura metinde "çıkarımsal gezintiler" yaptırır (2015: 69-70). Romanın bütününde dikkat çeken bu teknik -tekrara düşmemek amacıylaözellikle XI. bölümden hareketle ifade edilmeye çalışılacaktır.

"Yalnızlığın Oyuncakları" adlı bu bölümün oyalanma cümlesiyle başladığı söylenebilir: "Nihayet insanlık öldü." (2011: 255) Cümlenin devamında da araya giren başka anlatıcılarla oyalanma devam eder. "Yahu insanlık öldü mü", "İnsanlık 
öldü mü”, “İnsanlık ölür mü” sözleriyle çoğalan anlatıcılarla anlatım yavaşlar. Soyut bir kavramın ölümünü sorgulayan anlatıcılardan sonra Albay ve Hikmet arasındaki diyalog başlar. Kısa diyaloğun ardından anlatım yine yavaşlar ve öykünün dışından bir anlatıcı devreye girer: "Hikmet'in odasında oturuyorlardı. Kahvelerini içiyorlardı. İlkbahar gelmişti.” (2011: 257) Bu kısa bilgiden sonra Albay ve Hikmet arasındaki konuşmanın içeriği tamamen değişir ve Bilge hakkında konuşmaya başlarlar. Bölüm, sırasıyla Hikmet'in gördüğü rüya, ikisinin yazdığı oyun (Austerlitz Savaş1), bu oyunu bölen başka diyaloglar, Hikmet'in Bilge'yle kavgası, oyunun devamı, Doğu ve Batı üzerine konuşmalar ve Hikmet'in gecekondudan ayrılmasıyla son bulur. Atay, Hikmet'in bakış açısıyla soyut bir kavramı betimleyerek bölüme başlar. Ancak romanın bütününde de dikkat çektiği üzere anlatım sık sık bölünür. Oyun içinde oyun ile ilerleyen Atay, dışarıdan bir anlatıcıyı da kullanır. Dolayısıyla Hikmet Benol-Albay dışında üçüncü bir anlatıcı ve Austerlitz Savaşı'nın kahramanları da bölümde yer alır. Ayrıca "Yalnızlığın Oyuncakları"nda kurmaca, gerçek dünyanın çeşitli yönleriyle desteklenir. Sözgelimi tarihteki bir savaş, Sanayi Devrimi, Doğu-Batı ya da İngiliz-Türk ikilemi Hikmet Benol'un gözünden ifade edilir, anlatım ani yavaşlamalarla bölünür. Aşağıdaki şekilde olduğu gibi iç içe geçen bu düzlemlerde kurmaca dünya anlatıda geniş yer kaplar. Kurmaca içinde yer alan “oyun"lar ise ikinci halkayla; gerçeklik -bu iki düzlem içinde çoğu zaman kaybolmakla beraber- anlatının temel dayanağı olarak en küçük halkayla sembolize edilebilir.

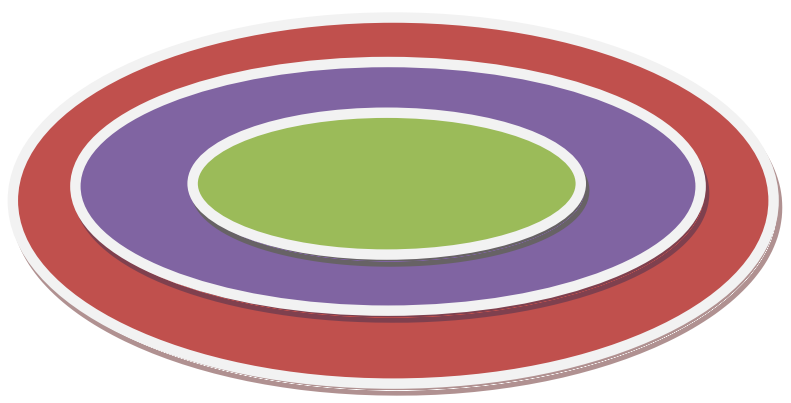

Şekil I

Gerçeklik-kurmaca-oyun halkası 


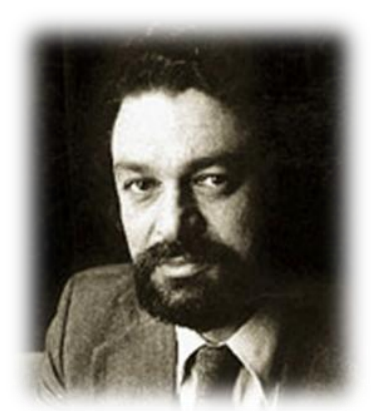

Buna göre insanlığın ölümünü sorgulayarak başlayan anlatıcının okuru oyalanmasının bir nedeni olmalıdır. Eco, bu türden bir anlatımı, örnek yazarın ya da metnin, okuru nasıl çıkarımsal bir gezinti yapmaya davet ettiğinin tipik bir örneği olarak değerlendirir (2015: 74). Atay da "insanlık öldü" sözlerini bölümün girişi dışında bir kez daha kullanır. Fakat bu bölümde, asıl vurgulanmak istenen Hikmet'in ruhunun derinlikleridir. Bölüm ilerledikçe “insanlığın ölümünün” nedeni Hikmet tarafından açığa kavuşturulur: "Bir haftadır görmedim onu. Kavga ettik, kapıyı vurup çıktım. Sonra yazdım 'İnsanlığın Ölümü'nü filan. Bilge'ye kızdığım için insanlığı öldürdüm." (2011: 276) Dolayısıyla bundan önceki yavaşlamaların nedeni anlaşılmış olur. Anlatıcının ya da anlatıcıların, gerçeği, rüyayı ve de kurmacayı birlikte kullanarak okuru zorlamaya çalıştığı düşünülebilir. Asıl nedenin anlaşılması için anlatısal oyalanmalara başvurulur ve özellikle bölümün giriş kısmı (insanlık öldü mü) dışında Hikmet’in gördüğü rüya ve Austerlitz Savaşı ile taktiksel oyalanmalar devam eder. Eco, anlatısal oyalanmanın nesnelerle, kişilerle ya da manzaralarla ilgili pek çok betimlemeyi kapsadığını belirtir. Bu türden oyalanmaların ortak amacının ise okuru bir sanat yapitı okuduğuna ikna etmek olduğunu ileri sürer. Yüksek nitelikli bir anlatıda böyle ayrıntıların kısa kesildiğini, niteliksiz bir anlatıda ise bolca kullanıldı̆̆ının altını çizer (2015: 91-92).

Bu durumda Atay'ın her bölümde bu türden oyalanmalara yer vermesi anlatıyı niteliksiz mi kılmıştır yoksa her ayrıntı okuru, nitelikli bir anlatı okuduğuna ikna etmek için mi kullanılmıştır? Giriş bölümünün okur için ikna edici olduğu söylenebilir. Hikmet'in iç sıkıntısının bu türden bir oyalanmayla karşılanması mümkün fakat rüyası ya da Austerlitz Savaşı'na yer verilmesi doğrudan bölümle ilgili bir oyalanma olarak değerlendirilmeyebilir. Bu türden oyalanmalar, romanın bütününde anlam kazanacak parçalar şeklinde ifade edilebilir. Dolayısıyla buradaki çıkarımsal gezintiler bütüne aittir. "Rüya" da söz konusu oyalanma bireyseldir ve asıl nedenle (Bilge) ilgisi yoktur: "Benim gibi korkakları, rüyalarında bile rahat 
bırakmıyorlar albayım. Bizim üniversitede bir hoca vardı, adı 'sosyal'le başlayan bir derse geliyordu. Rüyama girdi albayım. Fare olmuş ama başı gene kendi başı." (2011: 260) Fakat Austerlitz Savaşı'ndan önceki oyalanmalar, Hikmet'in dağınık iç hesaplaşmalarıyla ilgilidir. Dağınıklık Albay'ın uyarısıyla sonlandırılır: "İpin ucunu kaçırdık bir kere," diye homurdandı Hüsamettin Bey. "Bütün şahsi meselelerini ortaya dökmene göz yumduk. Bir türlü esas mevzuya giremiyorsun. Yahu şu piyesi hiç yazamayacak mıyız oğlum?" (2011: 263)

Bu bölümde Atay, genel olarak, yüzeysel olanın üzerinde ağır bir biçimde ilerler, asal olanı ise hızlı bir biçimde geçer. Hikmet'in yalnızlığının nedeni Bilge'dir ve Bilge'yle ilgili bölümlerde hızlı bir söylem zamanı dikkat çekerken diğer oyalanmalarda yavaş bir söylem zamanı ile yaratılan ritim söz konusudur. Eco'ya göre söylem zamanı "Okurun tepkisiyle etkileşim içinde olan, okura bir okuma zamanı kabul ettiren metinsel stratejinin sonucudur." (2015: 80) Atay'1 okurken okumanın ritmi sık sık bölünür veya yavaşlar. Genel olarak her oyalanmadan sonra o oyalanmayı bölen bir diyalog vardır. Ancak bu diyalog Hikmet ile Albay arasında olabileceği gibi onların kurmaca dünyasına ait bir diyalog da olabilir. Burada Eco'nun ortaya attığı başka bir kavram ortaya çıkar: Yayma. Yaymada öykünün hızına göre söylem yavaşlar ve metnin okura kabul ettirdiği "hız" esas alınır (2015: 72). Romanda kullanılan terimler, iç konuşmalar, semboller aracilığıyla okurun ilgisini çekme amacı güdülür. Bu nedenle de "yayma" -sinemadaki ağır çekim gibiokurun metinden zevk alması için yazarın dayattığı ritmi temsil eder. Sözgelimi, "Yalnızlığın Oyuncakları"nda anlatının dışından bir anlatıcı, mekân izlenimi vermek için söylem zamanını yayar:

“Hikmet çekmecesinin gözünden biraz kâğıt çıkardı; albayın getirdiği kitapları ve hazırladığı notları, masanın başında, birlikte okudular. Çaydanlık gaz ocağının üstüne konuldu. Sigaraları vardı. Tablaları çöp tenekesine döktüler, eski sigara dumanlarının kokusunu gidermek için pencereyi ve sokak kapısını açtılar, biraz cerayan yaptırdılar." (2015: 263-264) 
Eco'ya göre oyalanma her zaman soyluluğun göstergesi değildir. Zaman yitimine neden olan ve işlevsel olmayan her oyalanma "pornografik oyalanma"dır (2015: 83-88). Yukarıdaki oyalanmanın veya yaymanın metnin ritmini yavaşlattığı söylenebilir; aynı zamanda böyle bir oyalanmanın işlevsel olmadığı da savunulabilir. Peş peşe sıralanan ve anlatının ritmini düşüren oyalanmalardan bir kısmı doğrudan asal olanla (Bilge) ilgili değildir fakat bunların, romanın bütününe hizmet ettiği varsayılabilir. Ancak bu türden bir oyalamanın anlatıcı düzleminde bir karmaşa yaratmak dışında metne bir katkısının olmadığı da söylenebilir. Benzer şekilde, "Bütün gereksiz ayrıntıları ayıklamalıdır" diyen Hikmet Benol, alışılmışın dışında bir teknikle pek çok ayrıntıyı peş peşe sıralar: "Bir-dakika-yemek-yanıyor, şu-pencereyiaçar-mısın, kibriti-versene, kapı-çalınıyor, çöpü-kapıya-bırak." (2011: 286) Bu ani yavaşlama, oyalanmanın işlevlerinin hiçbirine örnek teşkil etmez, okurun ilgisini artırmadığ1 gibi, çıkarımsal bir gezinti yapmasına olanak da sağlamaz. Eco, oyalanmaların okura başarıyla sonuçlanacak bir tahminde bulunma olanağ sağladığını belirtir (2015: 71). Ancak öykünün dışından bir anlatıcı aracılığıyla yapılan bu türden oyalanmanın zaman yitimine neden olduğu da düşünülebilir. Bölümün devamında Hikmet Benol, Austerlitz Savaşı'ndaki Albay Mills üzerinden İngilizlerle ilgili fikirlerini ortaya koyar: “İngilizler her yerden çkarlar albayım, her yerde bulunurlar. Olayların dengesini sağlamak için muhakkak bulunurlar. Her şeyi onlara danışmak gerekir." (2011: 265) Oyun, onun Albay Hüsamettin Bey ve onun konuşmalarıyla sık sık bölünürken Austerlizt Savaşı'nın da metinde oyalanma taktiklerinden biri gibi işlev gördüğü fark edilir. Çünkü oyunu bölen Hikmet oyalanmanın nedenini yineler:

“Ona eziyet ediyorum albayım! diye bağırdı Hikmet. 'Ne var neden bağırıyorsun? Neyin var Hikmet?' ‘Onun canına okuyacak albayım! Yaşadığına pişman olacak zavallı kadın. Ona işkence ediyor albayım, ona işkence ediyorum. “Kime ediyorsun oğlum?' diye şaşkınlıkla sordu albay. Ona albayım Bilge'ye." (2011: 275) 
Bilindiği gibi Austerlitz Savaşı, 1805 yılında Fransa ile Rusya ve Avusturya arasında geçen ve Fransa'nın kesin zaferiyle sonuçlanan savaşlardan biridir. Savaş Napolyon ve I. Franz Mihail Kutuzov arasında geçer. Ancak Hikmet Benol, savaşın içeriğini tamamen değiştirir. O, Fransız General Schlick'in karısı Monika'ya yaptığı eziyeti ve bu eziyet üzerinden Bilge’yi anlatır. Bilge gibi kişisel bir konu üzerinden anlatıcı; İngilizleri, ülkesini ve kendi iç bunalımlarını ifade etmeye çalışır. Dolayısıyla Austerlitz Savaşı, Bilge hatta Sevgi onun iç çatışmalarının ögeleri olup hem anlatıdaki oyalanmaların nedeni hem de sonucu olarak değerlendirilebilir. Hikmet, “Durum gittikçe karışıyor albayım. Okudukça, düşündükçe, yeni insanlar tanıdıkça sadece günahlarının arttığını hissediyor. Ben bir hiçim albayım." sözleriyle içeriği değiştirir (284). Bölümün sonlarına doğru sözü Bilge'den Doğu-Batı arasındaki ayrima getirir:

“İktisatçlara göre, bizim geri kalmamızın ve İngilizlerin ilerlemesinin nedeni, onların gece yatısından vazgeçmeleriymiş. Onsekizinci Yüzyıl Sanayi devrimiyle birlikte gece yatısı âdeti de kalkmış. Çünkü, derebeyliğin zayıflamasıyla, toprağa bağlı köylüler ucuz emek olarak şehirlere akın etmeğe başlayınca, şehirdeki akrabaları onları yatıracak yer bulamaz olmuşlar. Sanayi burjuvası da öte yandan bu emekçilerin daha bir iş bulmadan akraba ve dost evlerinde gece yatısında kalmalarını ücretlerin yükselmesi bakımından sakıncalı görmüş." (2011: 288-289)

Hikmet Benol'a göre Doğu'da ise durum daha başkadır. O "yatıya kalma" fikrinden yola çıkarak Doğu-Batı veya İngiliz-Türk karşıtlığını şöyle ifade eder:

“Biz her zaman çay içebiliriz. Yemeğin verdiği ağırlıkla koltuklara serilince önce kahve, sonra çay içeriz. Göz kapakları uykudan ağırlaşan çocuklar, büyüklerin konuşmalarını dinlemeğe can attıkları için, bir türlü yatmak istemezler. Sen bizim Erkan'la yatarsın, yatak geniştir, denir çocuklara. Büyüklere yer yatağı serilir. Bütün işlerimizi böyle düzenleyebilseydik albayım, gece yatısı adetlerimize rağmen gene de İngilizleri geçerdik." (2011: 290) 
Bölümün sonunda oyalanmaların nedeni anlaşılmış olur. Anlatıcı, kişisel gibi algılanan problemi genelleştirerek İngilizler aracılığıyla hem özeleştirisini yapar hem de toplumla ilgili çıkarımlarda bulunur. Örnek okur da Hikmet Benol'un anlatıdaki gelgitlerinin kaynağını çözmüş olur. Bu durumda birinci neden onun geçmişi (Bilge, Sevgi), ikinci neden ise yalnızlığıdır. Bu yalnızlık ve hiçlik duygusu bireyselden evrensele geçişle ifade edilir. Ancak bölümdeki yavaşlamaların hepsinin bu geçişle doğrudan bir bağlantısı olmadığı savunulabilir. Aşağıdaki şekilden de anlaşıldığı üzere, Hikmet'in iç dünyası temel alındığında bazı oyalanmaların anlatıya işlevsel bir katkıda bulunduğu, bazısının da zaman yitimine neden olduğu fark edilir ve zamandaki bu kaybın bölüme katkısının olmadığı söylenebilir.

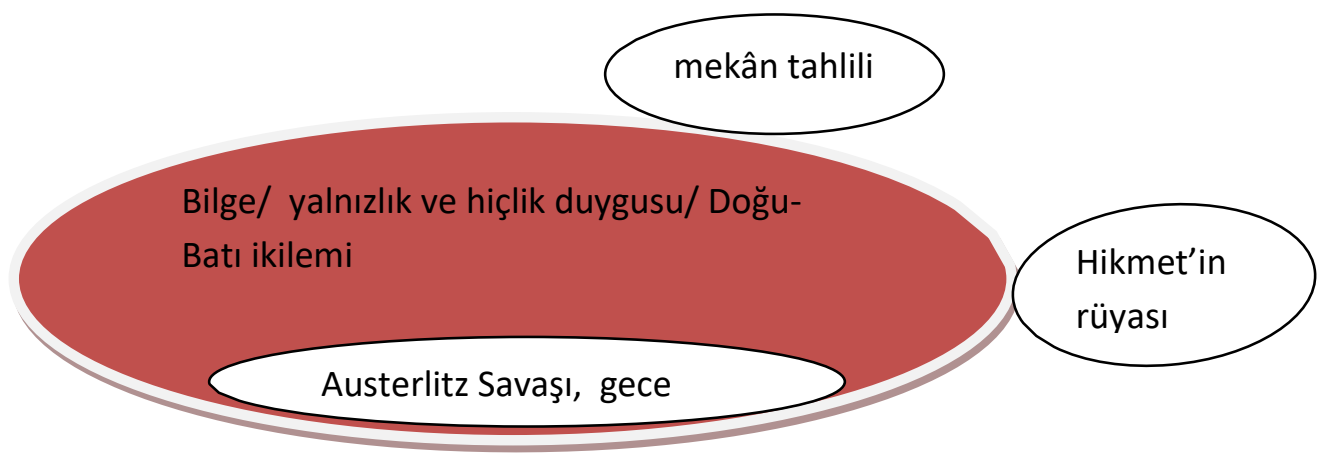

Şekil II.

İşlevsel-pornografik oyalanma

Bölümde tartışılacak diğer kavram "inançsızlığın askıya alınması” dır. Eco, bir anlatı metniyle karşı karşıya gelen okurun kurmaca antlaşmasını kabul etmesi gerektiğini savunur ve bunu inançsızlığın askıya alınması olarak tanımlar. Okur, kendisine anlatılanın hayal ürünü olduğunu bilmelidir fakat bu, yazarın yalan söylediği anlamına da gelmemelidir. Böylece okur, kurmaca anlaşmasını kabul eder ve yazarın anlattıkları gerçekten olmuş gibi davranır (2015: 101-102). Atay'da rüya, gerçek ve kurmaca iç içedir. Okur, Hikmet Benol'un hikâyesini okurken bu üç düzlemin yarattığı karmaşa karşısında yazarın yalan söylediğini düşünmez. Çünkü Atay, bu kafa karışıklığını tutarlı bir bütünlük oluşturacak biçimde kurgular. Ancak 
ilk bölümde de dikkat çektiği üzere bu, örnek okurun çözebileceği bir karmaşadır. Okur, romanın yalan söylediğini düşünmez çünkü yazar, romanda gerçek dünyayı art alan olarak kullanır. Eco, örneğin, Dönüşüm'de Gregor Samsa'nın böceğe dönüşmesi olayının inandırıcı olmamasına rağmen okur tarafından kabul edilebilir olduğunu belirtir. Böceğe dönüşmek olağandışı bir şeyken, böceğin yapısı bildiğimiz böceklerin yapısı gibidir. Dolayısıyla bu, gerçekliğin bir örneğini oluşturur (2015: 105-106). "Yalnızlığın Oyuncakları"nda da Austerlitz Savaşı sadece adıyla ve sonucuyla gerçekliği temsil eder. Savaşın ismi dışında her ayrıntı kurmaca dünyaya aittir. General Schlick'in karısı Monika'ya nefreti, Monika ve Heine arasındaki ümitsiz aşk ya da Schlick'in delirmesi tamamen gerçek dışıdır. Fakat anlatı, okuru bu kurmaca dünyanın sınırları içine alır ve onu ikna eder, okurun anlatılanları ciddiye almasını sağlar. Asıl mesele, "insanlığın ölümü”dür ki anlatıcının bu savaş üzerinden veya Bilge'yle ayrılığından yola çıkarak okuru ikna ettiği düşünülebilir. Böylece savaşın içeriğindeki değişimin nedeni anlaşılmış olur. Ayrıca anlatıcı, Sanayi Devrimi sonrasını anlatırken (gece yatısı âdeti) yine kurmacanın olanaklarını kullanır:

“Hükümet de bir bildiri yayımlayarak, sağlık bakımından sakıncalı olduğu gerekçesiyle bir evde gece yatısına ancak üç kişinin kalabileceğini, geri kalanların Düzeltme Evleri'ne gönderilerek delilerle birlikte zorla çalıştırılacağını ilân etmiş. Ayrıca, sanayicilerin baskısıyla yatak, yorgan, çarşaf, yastık, karyola, somya ve benzeri mamullere büyük ölçüde zam yapılmış. Gece yarıları evlere baskınlar yapılarak misafirler, yatak ve yorganlarıyla birlikte toplatılmış. William Astley Sheete'in bir raporuna göre, 1753 ocak ayında, yalnız Esat End ve Handers Lane' de 4248 yatakla 11376 çeşitli misafir yakalanmış." (201: 289)

Anlatıcı, inandırıcılığını arttırmak için sayısal verilerden yararlanır. Mutlak biçimde kurmacaya ait bu veriler art alanı kaba gerçekliğe yaslanan toplumsal bir olayla (Sanayi Devrimi) desteklenmiş, anlatı olanaklı hâle getirilmiştir. Gerçek dünyaya ait bir bilgi, bu gerçekdışı bilgileri olanaklı kılmak için çă̆rılmıştır. Fakat 
Eco'ya göre okur, gerçek dünyaya ait bilgelerinde yanılıyorsa ya da yanlış bilgi taşıyorsa "örnek okur" gibi davranmamış olur (2015: 123). Atay da romanda Türkiye'nin sosyal, kültürel ve siyasal durumuyla ilgili bilgi verir. Dolayısıyla okurun da belli birikimle romanı okuması gerektiği göze çarpar. Böylece okur, “inançsızlığı askıya alırken” anlatıda gerçeğin art alan olarak kullanıldı̆̆ını fark edecek ancak kurmacaya da sadık kalacaktır.

\section{Sonuç}

Tehlikeli Oyunlar, metnin sinırları dâhilinde ve Eco'nun ortaya attı̆̆ kavramlarla çözümlenmeye çalışılmıştır. Romanın sonuyla ilgili öne sürülen çelişik fikirler örnek okurun işbirliğiyle tartışılmış, gerçek ile kurmaca dünyanın silik ayrımında varlık kazanan roman kişileri, romandaki söylem olanakları dikkate alınarak ait oldukları dünya bakımından (kurmaca-gerçeklik) sınıflandırılmıştır. Ayrıca okuru metinde tahmine zorlayan ya da çıkarımsal gezintilere çıkaran “oyalanma"ların söylem zamanıyla ilişkisi tespit edilmiş, romanın bütününde dikkat çeken kaba gerçekliğe ait ögelerin metne katkısı gözler önüne serilmiştir. Buna göre roman, Eco'nun doğruluk ve yorumlayıcı işbirliği kavramları bakımından değerlendirildiğinde şu sonuçlara ulaşılmıştır: Nurhayat Hanım ve Albay Hüsamettin Tambay kurmaca dünyaya aittir. Gecekondu ile Hikmet'in intiharı örnek okurun işbirliği dikkate alınarak çözümlenmiş, bunların romanın kurmaca yanını temsil ettiği tespit edilmiştir. Buna karşılık üç katlı ahşap ev, Hikmet Benol, Sevgi ve Bilge romandaki gerçekliği temsil etmektedir. Romanın sonu ise uyku ile uyanıklık arasındaki bir hâl olarak yorumlanmıştır. Romanın bütününde dikkat çeken geriye sapmaların (analeks) geçmiş zaman ile şimdiki zaman arasında parçalı bir yapıya neden olduğu, bunun da okurun zihninde karmaşa yarattığı ve analekslerin romanda unutkanlığı giderme işleviyle ön plana çıkarıldığı fark edilmiştir.

Roman, söylem zamanı veya oyalama tekniği bakımından değerlendirildiğinde ise iç içe geçen düzlemlerde (kurmaca-gerçek), kurmaca dünyanın eserde geniş yer kapladığı saptanmıştır. Anlatıcının rüyayı, gerçeği ve 
kurmacayı bir arada kullanarak okuru zorladığı, romanda genel olarak yüzeysel olanın üzerinde ağır bir biçimde ilerleyen yazarın asal olanı hızlı bir biçimde geçtiği dikkat çekmiştir. Aynı zamanda Bilge'yle ilgili bölümlerde hızlı bir söylem zamanı gözlemlenirken diğer oyalanmalarda yavaş bir söylem zamanı ile bir ritim yaratıldığı görülür. Oyalanmalar, romanın bütününde anlam kazanacak parçalar olarak tanımlanmış ve Austerlitz Savaşı, Hikmet'in iç hesaplaşmaları, rüyaları taktiksel oyalanmalar olarak adlandırılmıştır. Benzer şekilde yazarın okura dayattığı ritim anlamına gelen "yayma", romanda iç konuşmalar, semboller, terimler kullanılarak ortaya çıkarılmıştır. Özellikle mekan izlenimi vermek amacıyla ritmin yavaşladığı, aynı zamanda bu türden oyalanmaların işlevsel olmadığı ve okurun çıkarımsal bir gezinti yapmasına olanak sağlamadığı gözlemlenmiştir.

Tehlikeli Oyunlar'da, üç düzlemle yaratılan karmaşa, tutarlı bir bütünlük oluşturacak biçimde kurgulanır ve gerçeklik art alan olarak kullanılır. Bu nedenle okurun kurmaca dünyanın sınırları içinde kaldığı, anlatıcının kurmaca üzerinden gerçekliğe yaslanan toplumsal olayları (Sanayi Devrimi) desteklediği ve bu yolla da anlatıyı olanaklı hâle getirdiği tespit edilmiştir. Belli bir birikimle romanı okuyan okurun inançsızlı̆̆ını askıya alabileceği, diğer bir deyişle, kurmacaya sadık kalabileceği belirtilmiştir.

\section{Kaynakça}

Atay, Oğuz (2011). Tehlikeli Oyunlar (25. basım). İstanbul: İletişim Yayınları.

Barthes, Roland (2013). Dilin Çalışma Sesi. Çev. Ayşe Ece ve diğerleri. İstanbul: Yapı Kredi Yayınları.

Barthes, Roland (2012). Eleştirel Denemeler. Çev. Esra Özdoğan. İstanbul: Yapı Kredi Yayınları.

Ecevit, Yıldız (2007). “Ben Buradayım...” Oğuz Atay'ın Biyografik ve Kurmaca Dünyası. (3. basım). İstanbul: İletişim Yayınları.

Eco, Umberto (2015). Anlatı Ormanlarında Altı Gezinti. Çev. Kemal Atay. 8. b., İstanbul: Can Yayınları. 
Genette, Gerard (2011). Anlatının Söylemi: Yöntem Hakkında Bir Deneme. Çev. Ferit Burak Aydar. İstanbul: Boğaziçi Üniversitesi Yayınevi.

Şahin, Yunus (2014). “Varoluş ve Bireyselleşme Bağlamında Oğuz Atay'ın Eserlerinin İncelenmesi". Yayımlanmamış doktora tezi. İstanbul: Fatih Üniversitesi.

Şenocak, Ahmet Erdem (2011). “Girard'ın Roman Kuramı Işı̆̆ında Bir Oğuz Atay Uyarlaması: Tehlikeli Oyunlar". Yayımlanmamış yüksek lisans tezi. İstanbul: İstanbul Üniversitesi. 